Фармацевтичний менеджмент, маркетинг та логістика

Pharmaceutical management, marketing and logistics

Рекомендована д. фрармац. наук, профр. Л. М. Унгурян

УДК 615.233:339.138 (477)

DOI 10.11603/2312-0967.2018.2.9126

\title{
ДОСЛІДЖЕННЯ АСОРТИМЕНТУ ВІДХАРКУВАЛЬНИХ ФІТОПРЕПАРАТІВ ДЛЯ ЛІКУВАННЯ КАШЛЮ ПРИ ПРОСТУДНИХ ЗАХВОРЮВАННЯХ
}

\author{
(c) С. Я. Белей, Т. А. Грошовий, Н. М. Белей, Н. П. Дарзулі \\ ДВНЗ «Тернопільський державний медичний університет імені І. Я. Горбачевського \\ МОЗ України» \\ beley@tdmu.edu.ua
}

\begin{abstract}
Мета роботи. Провести аналіз асортименту відхаркувальних лікарських засобів (ЛЗ) рослинного походження, які зареєстровані в України і застосовуються для лікування кашлю при простудних захворюваннях.

Матеріали і методи. Загальноприйняті статистичні та маркетингові дослідження паперових та електронних джерел інформації щодо ЛЗ даної фрармакологічної групи.

Результати й обговорення. Статтю присвячено аналізу асортименту відхаркувальних ЛЗ рослинного походження, зареєстрованих в Україні. Визначено основні закономірності асортиментної політики фрармацевтичних виробників щодо ЛЗ для лікування кашлю при простудних захворюваннях.

Висновки. Встановлено, що в Україні станом на січень 2018 р. група відхаркувальних ЛЗ рослинного походження налічує 90 зареєстрованих торгових назв (ТН), більшість з них - комбіновані Л3, частка яких становить 37 \%. Серед усіх ЛФ сиропи займають 36 \%, частка зборів становить $26 \%$, і вони представлені лише вітчизняними виробниками. Лз у формі таблеток займають третє місце серед вітчизняних Лз та їх частка становить 12 \%.
\end{abstract}

Ключові слова: кашель; Державний реєстр лікарських засобів України; відхаркувальні засоби; лікарська рослинна сировина.

Вступ. Кашель - один з найпоширеніших симптомів, з яким пацієнти звертаються за медичною допомогою до лікарів первинної медичної допомоги та пульмонологів [1]. Статистичні дослідження, проведені в Австралії та Сполучених Штатах Америки, також показують, що кашель є однією 3 найбільш поширених скарг, 3 якою пацієнти різного віку звертаються до лікарів в амбулаторних умовах. Опитування в Японії та Великій Британії свідчать, що поширеність хронічного кашлю серед населення становить 10,2 і $12 \%$ відповідно [2]. Даних щодо поширення кашлю серед населення України немає через те, що кашель - це симптом, який може бути присутнім при багатьох захворюваннях. В більшості випадків кашель пов'язаний 3 гострими респіраторними інорекціями (застудою) [3, 4]. Важливим патогенетичним механізмом, який призводить до порушення прохідності дихальних шляхів, $€$ утворення в'язкого мокротиння. Для його розрідження і видалення використовуються відхаркувальні лікарські препарати, які впливають на очищення трахеобронхіального дерева від скупчення бронхіального секрету, слизу і гною [5].

Матеріали і методи. Загальноприйняті статистичні та маркетингові дослідження паперових та електронних джерел інформації щодо лз даної фрармакологічної групи. Аналіз асортименту лз проводили за Державним реєстром Л3 [6] та інтернет-ресурсами «GeoApteka» [7], «Tabletki.ua» [8]
Результати й обговорення. Згідно з даними Державного реєстру Лз України станом на січень 2018 р. група відхаркувальних ЛЗ рослинного походження налічує $90 \mathrm{TH}$.

Відповідно до АТС класиорікації, проаналізовані лз рослинного походження, які використовуються як відхаркувальні, належать до головної терапевтичної групи R05 «Засоби, що застосовуються у разі кашлю та застудних захворювань», і підгрупи R05C A «Відхаркувальні засоби». За видом лікарської рослинної сировини вони розділені на 15 підгруп (рис. 1).

Фітопрепарати, до складу яких входить декілька діючих фрітосубстанцій, належать до R05C A10 «Комбінації», які займають найбільшу частку, що становить 37 \%, та налічують 34 TH.

Було проведено аналіз зареєстрованих відхаркувальних ЛЗ за лікарською фрормою (ЛФ) (рис. 2).

3 даних рисунка 2 видно, що сиропи (13 TH) $є$ найбільш популярною ЛФ серед комплексних ЛЗ. Варто зазначити, що дана ЛФ однаковою мірою $є$ фрормою вибору як зарубіжних виробників, так і вітчизняних. Вітчизняні виробники пропонують наступні ЛЗ: Алтемікс бронхо (ТОВ «Фармацевтична компанія «Здоров'я»), Пертусин у формі сиропу випускають 3 виробники: ПАТ «Галичфрарм» Корпорація «Артеріум», ТОВ «Терносрарм», ПрАТ «Фітофрарм»), Сироп подорожника (ТОВ «Тернофрарм»), Фітобронхол (Прат «Ліктрави»). До закордонних ЛЗ у фрормі сиропів належать: Гербіон

ISSN 2312-0967. Фармацевтичний часопис. 2018. № 2 
Фармацевтичний менеджмент, маркетинг та логістика Pharmaceutical management, marketing and logistics

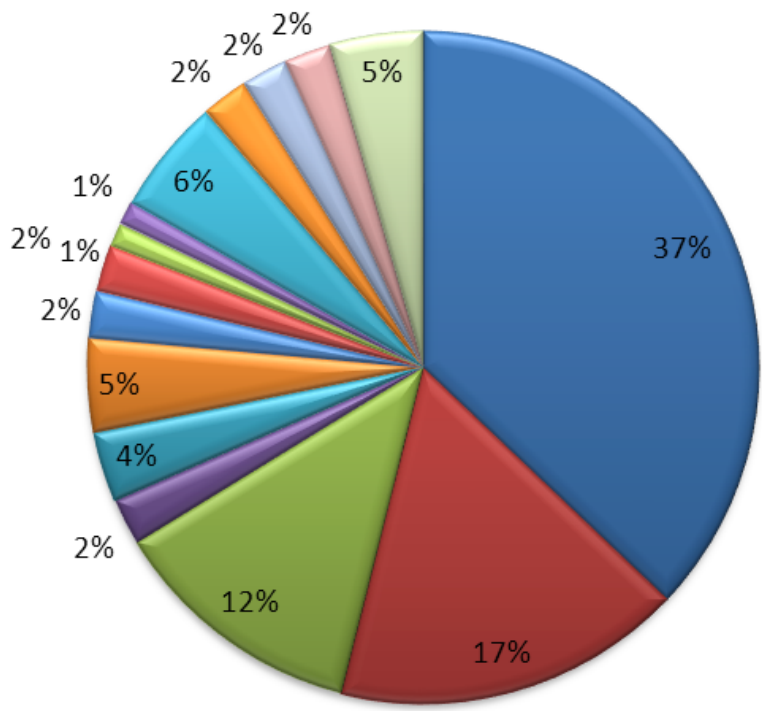

$\square$ Комбінації
$\square$ Листя плюща
$\square$ Коріння алтеї
$\square$ Сосни бруньки
$\square$ Препарати подорожника
$\square$ Препарати чебрецю
$\square$ Міртол
$\square$ Листя підбілу
$\square$ Препарати анісу
$\square$ Препарати багна
$\square$ Корінь солодки
$\square$ Корінь оману
$\square$ Трава материнки
$\square$ Трава фіалки
$\square$ Інші

Рис. 1. Розподіл рослинних відхаркувальних ЛЗ за видом лікарської сировини згідно з АТС класиорікацією.

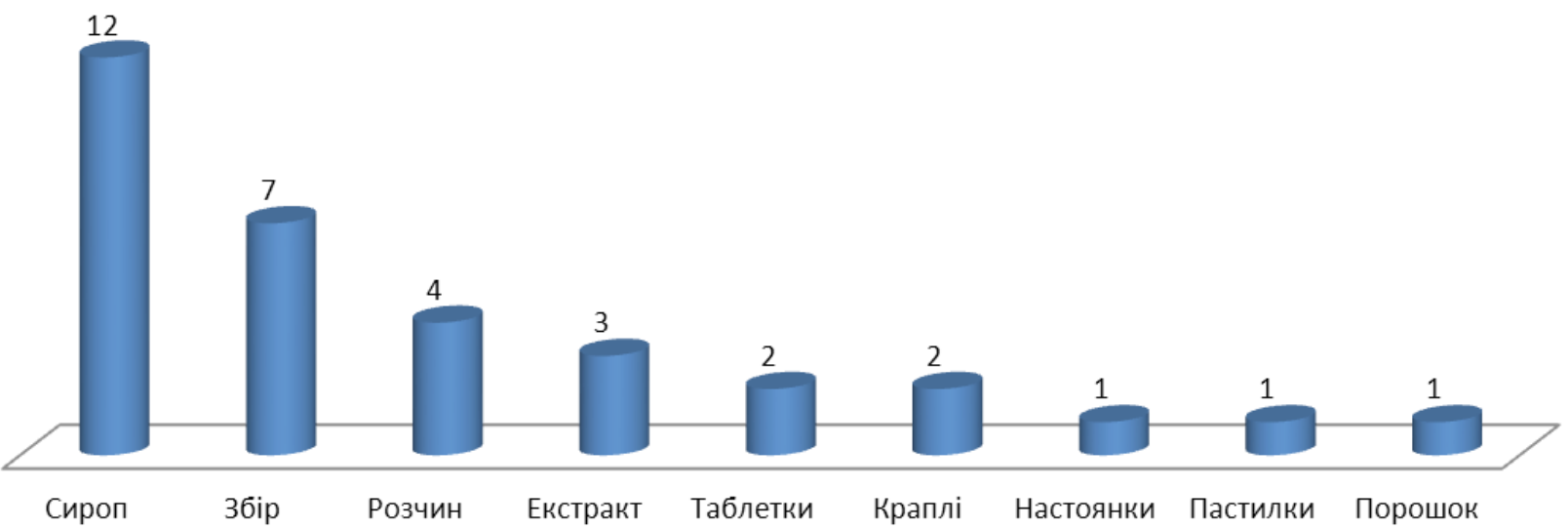

Рис. 2. Розподіл комбінованих відхаркувальних рослинних Лз за видом ЛФ.

сироп первоцвіту і Гербіон сироп подорожника (KRKA д.Д., Ново место, Словенія), Доктор кашель (Люпін Лімітед, Індія), Евкабал (Фарма Вернігероде ГмбХ, Німеччина), Сироп від кашлю з подорожником і мати-й-мачухою (Херкель Б.В., Нідерланди), Стоптусин фріто (Тева Чех Індастріз с.р.о., Чеська Республіка), Тусавіт (Фармацеутіше фрабрік Монтавіт ГмбХ, Австрія).

ЛЗ у формі зборів представлені 7 позиціями і вони $\epsilon$ лише вітчизняного виробництва (ПАТ «Лубнифрарм», ТОВ «Науково-виробнича фрармацевтична компанія «ЕЙМ», ПрАТ «Віола», ПрАТ «Ліктрави»); зарубіжні виробники не пропонують зборів даної фрармакологічної групи.

До розчинів відносяться чотири лз: Бронхостоп (Квізда Фарма ГмбХ, Австрія), Парален (Ей. Наттерманн енд Сайі ГмбХ, Німеччина), Пертусин (Комунальне підприємство «Луганська обласна «Фармація»), Грудні краплі від кашлю (ТОВ «Тернофрарм»).

Л3 в формі екстракту випускаються компаніями ПАТ «Фармак» (Пектолван фріто ісландський мох, Пектолван фріто) та ПрАТ «Віола» (Пертусин).
До таблетованих ЛЗ відносяться Мукалтин ${ }^{\circledR}$ Форте (ПАТ «Галичфрарм» Корпорація «Артеріум») та Евкаліпт-М (Херкель Б.В., Нідерланди). Краплі випускають Др. Тайсс Натурварен ГмбХ, Німеччина (Бронхо Тайсс) та Нашатирно-анісові краплі (ТОВ «Тернофрарм»).

При цьому зареєстрований лише один ЛЗ у формі настойки Бронхофріт (ТОВ «Науково-виробнича фрармацевтична компанія «ЕЙМ»), один у вигляді порошку для приготування мікстури Аріда ${ }^{\circledR}$ Суха мікстура від кашлю для дітей (ТОВ «Тернофрарм») та один - у формі пастилок Евкаліпт М (Херкель Б.В., Нідерланди).

Всі наступні підгрупи - це монопрепарати рослинного походження. Вони представлені 56 ТН, що становить 63 \% від загальної кількості Л3.

Підгрупа, яка займає 17 \% та налічує 15 л3, є R05C A12 «Листя плюща». Особливостями підгрупи $€$ те, що 12 ТН (80 \%) є закордонного виробництва, здебільшого у фрормі сиропу та крапель. Вітчизняні виробники пропонують три ЛЗ: Пектолван плющ сироп і Плюфоркаф у формі капсул виробництва ПАТ

ISSN 2312-0967. Pharmaceutical review. 2018. № 2 
Фармацевтичний менеджмент, маркетинг та логістика Pharmaceutical management, marketing and logistics

«Фармак» та Гедерин «ТОВ «ДКП Фармацевтична фрабрика».

До підгрупи R05CA05 «Корені алтеї» входить 11 монопрепаратів, дебільшого у фрормах таблеток та сиропу, що складає 12 \% зареєстрованих відхаркувальних Л3. Особливостями даної групи є те, що всі ЛЗ виробляються в Україні. Лідерами серед виробників $€$ ПАТ «Галичфрарм» Корпорація «Артеріум» - 4 ТН, ТОВ «Тернофрарм» - дві. В даній групі переважають таблетки (6 ТН), 4 Л3 у фрормі сиропу та один збір.

Л3 підгрупи R05C A23** «Корінь солодки» у фрормі сиропу (4 TH) та збір (одна ТН), що складає 6 \%, які представлені лише вітчизняними виробниками.

Підгрупа R05C A18** «Препарати чебрецю» представлені $4 \mathrm{TH}$ (4 \%): Бронхостоп в фрормі пастилок (Квізда Фарма ГмбХ, Австрія), Парален у фрормі сиропу (Ей. Наттерманн енд Сайі ГмбХ, Німеччина) і пастилок (Санофрі-Авентіс Сп. з о.о., Польща) та Чебрецю трава (ПрАТ «Ліктрави»).

R05CA50** «Інші підгрупа», до якої входять 5 Л3 (5 \%): Антитусин таблетки (ТОВ «Тернофрарм»), Геделікс капсули (Кревель Мойзельбах ГмбХ, Німеччина), Мукалтин форте з вітаміном С таблетки (ПАТ «Галичфрарм» Корпорація «Артеріум»), Тавіпек капсули (Фармацеутіше фрабрік Монтавіт ГмбХ, Австрія), Сироп подорожника на основі подорожника ланцетолистого і мальви лісової (KRKA д.Д., Ново место, Словенія).

R05CA17** «Препарати подорожника» представлені 3 ТН (3 \%): Подорожника великого листя (ПрАТ «Ліктрави», ПрАТ «Віола») та Сироп від кашлю Др. Тайсса (Др. Тайсс Натурварен ГмбХ, Німеччина).

Двома Л3, що складає 2 \%, представлені підгрупи: R05C A15** «Сосни бруньки» (Сосни бруньки, ПрАТ «Віола», ПрАТ «Ліктрави»), R05C A19 Міртол (Гело-

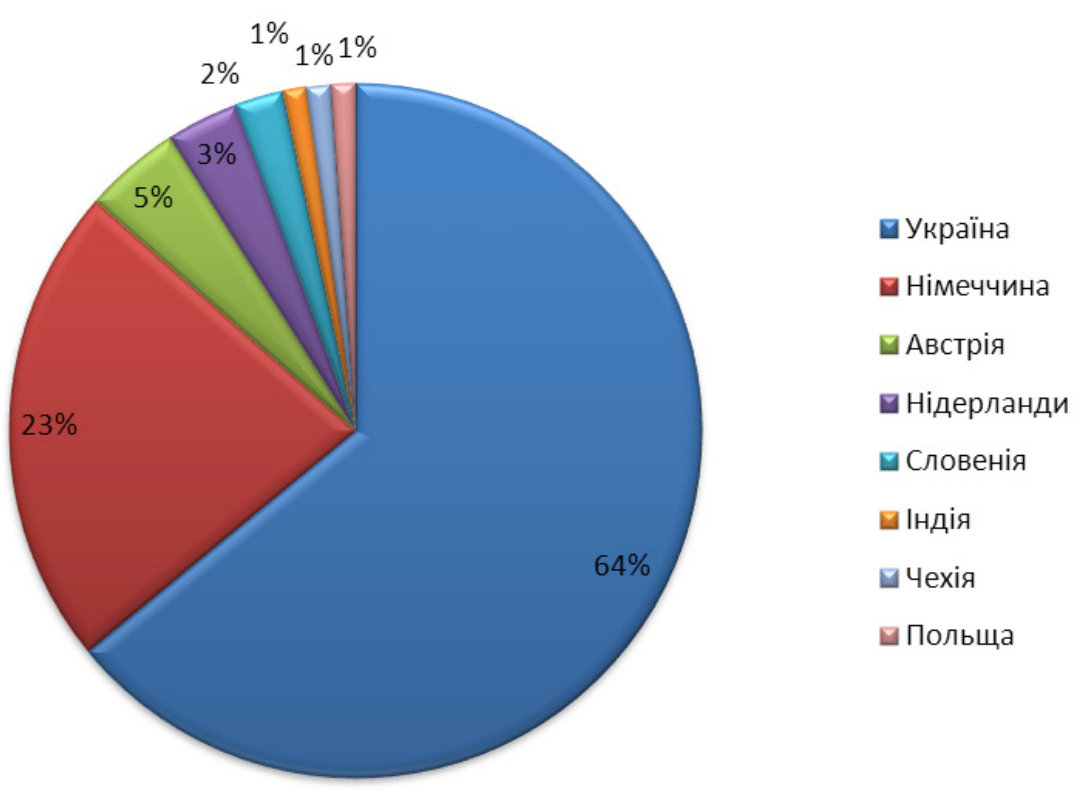

Рис. 3. Розподіл відхаркувальних рослинних ЛЗ за країною виробником. миртол форте, Геломиртол Г. Поль-Боскамп ГмбХ \& Ко. КГ. Німеччина), R05C A20** «Листя підбілу» (Мати-й-мачухи листя, ПрАТ «Віола», ПрАТ «Ліктрави»), R05C A24** «Корінь оману», (Оману кореневища 3 коренями, ПрАТ «Віола», ПрАТ «Ліктрави») R05C A25** «Tрава материнки» (Материнки трава, ПрАТ «Віола», ПрАТ «Ліктрави»), R05C A26** «Трава фріалки» (Фіалки трава, ПрАТ «Віола», ПрАТ «Ліктрави»). Одним ЛЗ представлені кожна підгрупа R05CA21** «Препарати анісу» (Капсули 3 анісовою олією, Др. Тайсс Натурварен ГмбХ, Німеччина) і R05CA22** «Багно звичайне» (Багна звичайного пагони, ПрАТ «Віола») кожна.

Аналізуючи стан реєстрації відхаркувальних лЗ встановлено, що ЛЗ вітчизняного виробництва займають 64 \%, що налічує 57 ТН (рис. 3).

Зарубіжні ЛЗ займають $36 \%$, серед них значну частку, а саме $23 \%$, становлять Л3 виробництва Нiмеччини. Решта ЛЗ різних закордонних виробників розподілені таким чином: чотири Л3 (5 \%) виробництва Австрії, Нідерландів - 3 (3\%), Словенії - три л3 (3 \%), Індії, Чехії і Польщі по одній ТН, що становить $1 \%$.

Варто зазначити, що в 2017 р. аналіз Лз терапевтичної підгрупи R05C A (відхаркувальні засоби) за країнами виробниками проводився науковцями Національного фрармацевтичного університету і було встановлено, що співвідношення ЛЗ вітчизняних компаній-виробників до іноземних становило на той час 79,2 до 20,8 \% [9]. На сьогодні це співвідношення змінилося - 64 до 36 \%, що говорить про тенденцію до зменшення частки зареєстрованих в Україні відхаркувальних ЛЗ вітчизняного виробництва.

Дані діаграми підтверджують, що серед усіх ЛФ позиції лідерів зареєстрованих відхаркувальних лЗ займають сиропи - 36 \%, на другому місці стоять збо-

ISSN 2312-0967. Фармацевтичний часопис. 2018. № 2 
Фармацевтичний менеджмент, маркетинг та логістика

Pharmaceutical management, marketing and logistics

ри на основі ЛРС - 26 \%, третю позицію займають таблетки - $12 \%$.

Розчини та капсули займають по 7 \% кожна ЛФ, краплі 6 \%, 4 \% - пастилки, 1 \% настойки та порошки (рис. 4).

3 аналізу стану реєстрації відхаркувальних ЛЗ можна чітко побачити різницю між ЛФ, яким надають перевагу вітчизняні і зарубіжні виробники. Значну перевагу закордонні виробники надають сиропам, у відсотковому співвідношенні (44 \%) вони є беззаперечними лідерами. Майже одинакові позиції займають капсули (16\%), розчини та пастилки (13\%). Краплі (9 \%) та таблетки (6 \%) значно поступаються іншим ЛФ.
3 даних рисунка 5 видно, що вітчизняні виробники надають перевагу таким ЛФ, які вже не зустрічаються за кордоном - збори, настойки, порошки. Особливо слід вказати на велику кількість зборів (23 ТН), вони займають першу позицію серед ЛФ вітчизняних виробників, що становить $40 \%$. Значну частку займають сиропи 32 \% та таблетки 16 \%. Серед українських виробників не користуються популярністю капсули (2 \%) та пастилки (відсутні), в той час як зарубіжні виробники надають їм перевагу, вони є альтернативою таблеткам. Краплі та розчини майже однаково представлені як зарубіжними, так і вітчизняними виробниками.

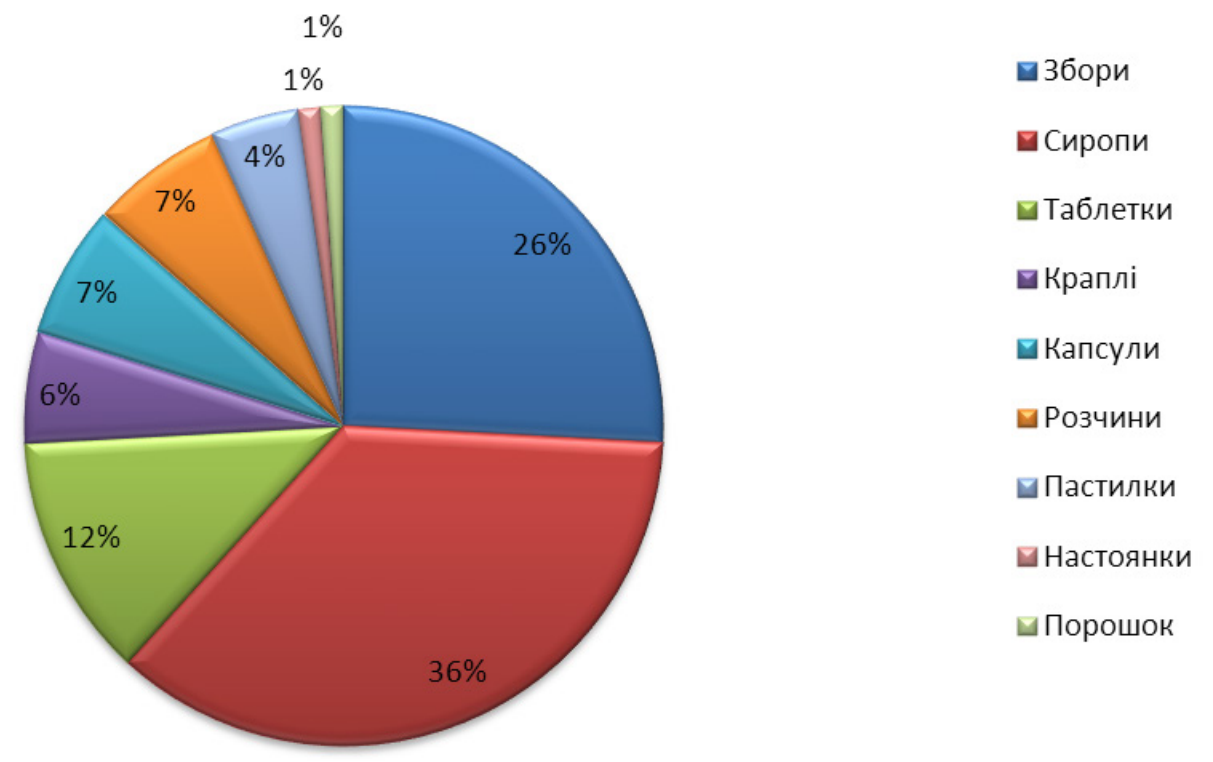

Рис. 4. Розподіл відхаркувальних фрітопрепаратів за ЛФ.

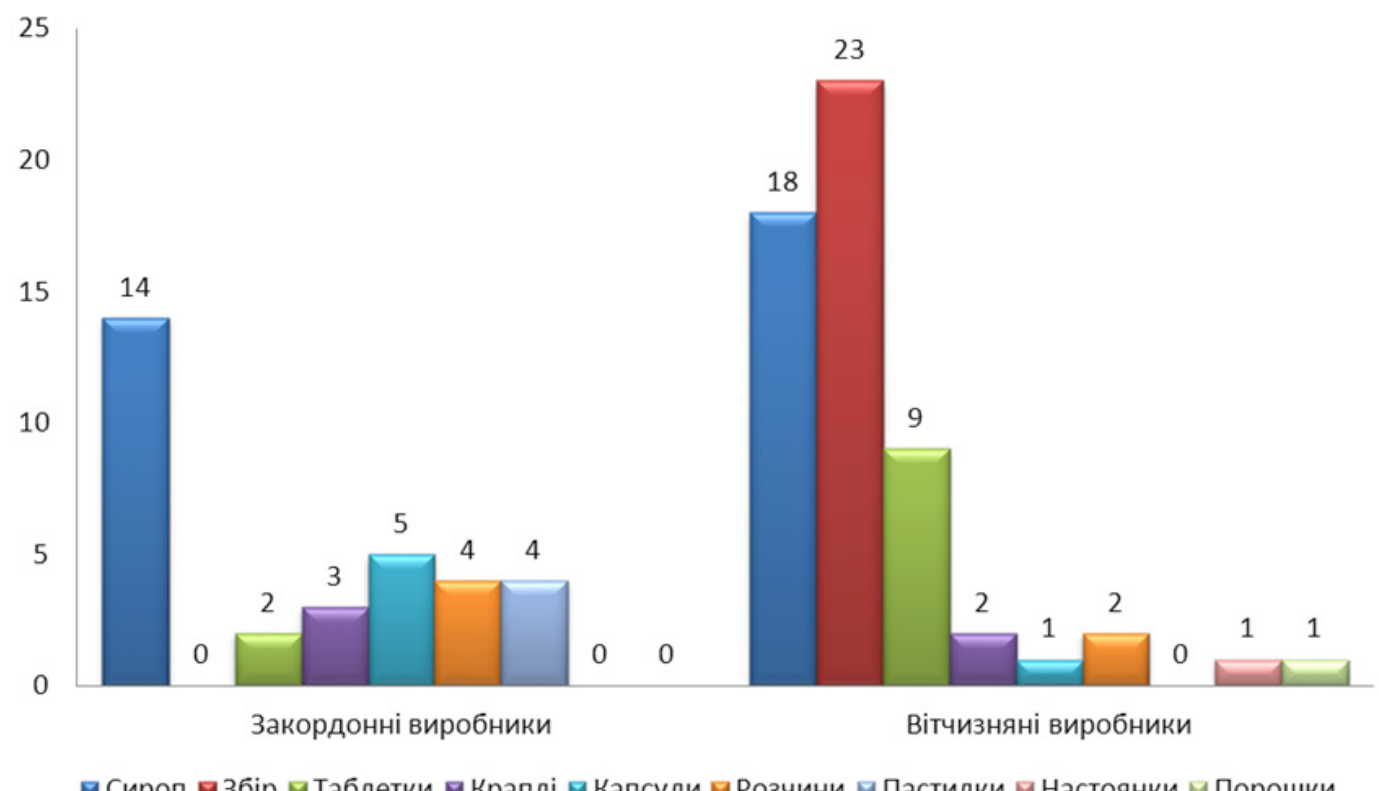

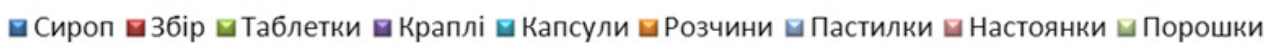

Рис. 5. Розподіл відхаркувальних Лз вітчизняних та зарубіжних виробників за ЛФ.

ISSN 2312-0967. Pharmaceutical review. 2018. № 2 
Фармацевтичний менеджмент, маркетинг та логістика Pharmaceutical management, marketing and logistics

Висновки. 1. Згідно з даними Державного реєстру лЗ України, станом на січень 2018 року, група відхаркувальних Л3 рослинного походження, що належать до групи R05 «Засоби, що застосовуються у разі кашлю та застудних захворювань», R05CA «Відхаркувальні засоби», налічує $90 \mathrm{TH}$.

2. Аналіз стану реєстрації рослинних відхаркувальних ЛЗ показав, що позиції лідерів займають

комбіновані Л3, частка яких становить 37 \%. Серед усіх ЛФ сиропи займають 36 \% від загальної кількості як комбінованих, так і монопрепаратів даної групи, частка зборів становить $26 \%$ і вони представлені лише вітчизняними виробниками. Відхаркувальні лЗ у формі таблеток займають третє місце серед вітчизняних ЛЗ та їх частка серед зареєстрованих в Україні ЛЗ становить $12 \%$.

\title{
ИССЛЕДОВАНИЕ АССОРТИМЕНТА ОТХАРКИВАЮЩИХ ФИТОПРЕПАРАТОВ, ПРИМЕНЯЕМЫХ ДЛЯ ЛЕЧЕНИЯ КАШЛЯ ПРИ ПРОСТУДНЫХ ЗАБОЛЕВАНИЯХ
}

\author{
С. Я. Белей, Т. А. Грошовый, Н. Н. Белей, Н. П. Дарзули \\ гвУЗ «Тернопольский государственный медицинский университет имени И. Я. Горбачевского Мз \\ Украины» \\ beley@tdmu.edu.ua
}

Цель работы. Провести анализ ассортимента отхаркивающих лекарственных средств (ЛС) растительного происхождения, которые зарегистрированы в Украине и применяются для лечения кашля при простудных заболеваниях.

Материалы и методы. Общепринятые статистические и маркетинговые исследования бумажных и электронных источников информации о лекарственных средствах данной фрармакологической группы.

Результаты и обсуждение. Статья посвящена анализу ассортимента отхаркивающих лекарственных средств растительного происхождения, зарегистрированных в Украине. Определены основные закономерности ассортиментной политики фрармацевтических производителей относительно препаратов для лечения кашля при простудных заболеваниях.

Выводы. Установлено, что в Украине на январь 2018 года, группа отхаркивающих лс растительного происхождения насчитывает 90 торговых названий, большинство из них - комбинированные ЛС, доля которых составляет 37 \%. Среди всех ЛФ сиропы занимают 36 \%, процент сборов - 26 \% и они представлены только отечественными производителями. ЛС в форме таблеток стоят на третьем месте среди отечественных ЛС и их доля на фрармацевтическом рынке Украины составляет $12 \%$.

Ключевые слова: кашель; Государственный реестр лекарственных средств Украины; отхаркивающие средства; лекарственное растительное сырье.

\section{INVESTIGATION OF THE ASSORTMENT OF HERBAL EXPECTORANTS USED FOR TREATMENT OF COUGH AT COLDS}

\section{S. Ya. Beley, T. A. Hroshovyi, N. M. Beley, N. P. Darzuli}

\section{Horbachevsky Ternopil State Medical University}

beley@tdmu.edu.ua

The aim of the work. To carry out an analysis of the assortment of expectorants (drugs) of herbal origin used for treatment of cough at colds which are registered in Ukraine.

Materials and Methods. Generally accepted statistical and marketing research of paper and electronic sources concerning medicines of the given pharmacological group.

Results and Discussion. The article is devoted to analysis of the assortment of expectorant of herbal origin registered in Ukraine. The basic regularities of the assortment policy of manufacturers concerning drugs for the treatment of cough at colds are determined.

Conclusions. It is established that in Ukraine as on January 2018, a group of expectorant of herbal origin contains 90 registered trade names (TN). Most of them are multi-component drugs which form $37 \%$ of the total number. Among all dosage forms, syrups occupy $36 \%$ of the total, while the herbal tea share is $26 \%$ and they are only represented by domestic manufacturers. Medicinal products in the form of tablet holds $12 \%$ market of drugs and they take the third place among domestic medicines.

Key words: cough; State Register of Medicinal Products of Ukraine; expectorants; herbal raw material.

ISSN 2312-0967. Фармацевтичний часопис. 2018. № 2 
Фармацевтичний менеджмент, маркетинг та логістика Pharmaceutical management, marketing and logistics

\section{Список літератури}

1. Cough management: a practical approach / F. D. Blasio, J. C. Virchow, M. Polverino [et al.]. - 2011. [Electronic resource]. - Mode access: https://www.ncbi.nlm.nih.gov/pmc/ articles/PMC3205006/.

2. Overview of the Management of Cough. Guideline and Expert Panel Report / R. S. Irwin, T. Cynthia, S. Zelman Lewis [et al.] // Chest. - 2014. - No. 146 (4). - P. 885-889. 3. Про затвердження та впровадження медико-технологічних документів зі стандартизації медичної допомоги при кашлі : наказ № 327 від 08.06.2015 Міністерство охорони здоров'я України [Електронний ресурс]. - Режим доступу: https://www.zakon-i-normativ.info/index.php/component lica/ ?href=0\&view=text\&base $=1 \&$ id=831820 \&menu=12350502 4. Уніфікований клінічний протокол первинної медичної допомоги. Кашель у дорослих. - Міністерство Охорони Здоров'я України. - 2015. - 28 с.

\section{References}

1. Blasio FD, Virchow JC, Polverino M, Zanasi A, Behrakis PK, Kilinç G, Balsamo R, Danieli GD, Lanata L. [Cough management: a practical approach] 2011. Available from: https://www.ncbi.nlm.nih.gov/pmc/articles/PMC3205006/. [Accessed February 2018].

2. Irwin RS, Cynthia T, Zelman Lewis S, Diekemper RL, Gold PhM. [Overview of the Management of Cough. Guideline and Expert Panel Report] Chest. 2014;146(4): 885-9. 3. Ministry of Health of Ukraine. Order No. 327 of 06/08/2015 On Approval and Implementation of Medical-Technological Documents for the Standardization of Medical Aid at Cough. [Electronic resource]. Available from: https://www.zakon-i-normativ.info/index.php/component/lica/?href=0\&view=text\&base $=1 \& i d=831820 \&$ menu=12350502. [Accessed February 2018].
5. Єфрімова С. В. Симптом кашлю в практиці лікаряпедіатра: сучасні аспекти вибору муколітичної терапії / С. В. Єфрімова, О. І. Мацюра // Современная педиатрия. - 2015. - T. 2, № 66. - С. 48-51.

6. Державний реєстр лікарських засобів України [Електронний ресурс]. - Режим доступу: http://www.drlz. kiev.ua.

7. GeoApteka [Electronic resource]. - Mode access: https:// geoapteka.com.ua.

8. Tabletki.ua [Electronic resource]. - Mode access: https:// tabletki.ua.

9. Кухтенко О. С. Аналіз вітчизняного ринку лікарських засобів для лікування запальних захворювань дихальних шляхів / О. С. Кухтенко, Є. В. Гладух, Л. С. Сімонян // Управління, економіка та забезпечення якості в фрармації. - № 4 (52). - 2017. - С. 42-49.

4. Unified clinical protocol for primary care. Adults cough. Ministry of Health of Ukraine. 2015:28.

5. Yefimova SV, Matyura OI. [Symptom of cough in the practice of a pediatrician: modern aspects of the choice of mucolytic therapy] Modern pediatrics. 2015;2(66): 48-51. Ukrainian.

6. The State Register of Medicinal Products of Ukraine [Electronic resource, Ukrainian]. Available from: http://www. drlz.kiev.ua. [Accessed February 2018].

7. GeoApteka [Electronic resource, Russian]. Available from: https://geoapteka.com.ua. [Accessed February 2018]. 8. Tabletki.ua [Electronic resource, Russian]. Available from: https://tabletki.ua. [Accessed February 2018].

9. Kukhtenko OS, Gladukh EV, Simonyan LS. [Analysis of the domestic market for drugs for the treatment of inflammatory diseases of the respiratory tract] Management, economics and quality assurance in pharmacy. 2017;4(52): 42-9. Ukrainian. 